\title{
Estimating the global trade in Southeast Asian Newts
}

Jodi J. L. Rowley ${ }^{a^{*}}$, Chris R. Shepherd ${ }^{b}$, Bryan L. Stuart ${ }^{\mathrm{c}}$, Truong Q. Nguyen ${ }^{\mathrm{d}}$, Huy D. Hoang ${ }^{\mathrm{e}}$, Timothy P. Cutajar ${ }^{\mathrm{a}}$, Guinevere O. U. Wogan ${ }^{\mathrm{f}}$, Sompouthone Phimmachak ${ }^{\mathrm{g}}$

${ }^{a}$ Australian Museum Research Institute, 1 William St, Sydney NSW 2010, Australia. jodi.rowley@austmus.gov.au

${ }^{b}$ TRAFFIC in Southeast Asia, Unit 3-2, $1^{\text {st }}$ floor, Jalan SS23/11, Taman SEA, 47400 Petaling Jaya, Selangor, Malaysia chris.shepherd@traffic.org

${ }^{c}$ North Carolina Museum of Natural Sciences, 11 W. Jones St., Raleigh, North Carolina 27601 USA. bryan.stuart@naturalsciences.org

${ }^{d}$ Institute of Ecology and Biological Resources, Vietnam Academy of Science and Technology, 18 Hoang Quoc Viet Road, Hanoi, Vietnam.nqt2@yahoo.com

${ }^{e}$ Viet Nam National University Ho Chi Minh City-University of Science, Faculty of Biology, 227 Nguyen Van Cu, District 5, Ho Chi Minh City,Vietnam.E-mail: hdhuy@hcmus.edu.vn

${ }^{f}$ University of California, Berkeley. Department of Environmental Science, Policy, and Management; and Museum of Vertebrate Zoology. 3101 Valley Life Sciences Bldg., Berkeley CA 94720, USA. gwogan@berkeley.edu ${ }^{g}$ National University of Laos, Faculty of Sciences, Department of Biology, P. O. Box 2273, Dong Dok Campus, Vientiane Capital, Laos.somphouthone26@hotmail.com

\section{Corresponding author:}

Jodi J. L. Rowley

Australian Museum Research Institute, 1 William St, Sydney NSW 2010, Australia. jodi.rowley@austmus.gov.au

+61293206014 


\begin{abstract}
The global trade in amphibians is widespread, involves hundreds of species, and has been implicated in amphibian population declines. The pet trade is the primary driver for population declines in one Southeast Asian newt species (Laotriton laoensis), and is a known threat to most of the 14 other known species from the region. Despite this, there has been little attempt to assess the impact of collection for the pet trade on Southeast Asian newts. We examined available import data from the US, Europe and Hong Kong, assessed current online trade and surveyed local pet traders within Southeast Asia. Large numbers of Southeast Asian newts are harvested from the wild to meet the demands of the international pet trade, with more than 7500 individual newts imported into the US alone during 2005-2014. Internet trade surveys revealed the global extent of the trade, with Southeast Asian newts for sale as pets in 15 countries throughout Europe, Asia and North America, at between US\$30-260 each. The trade in newts within Southeast Asia appears negligible in comparison. Urgent measures are required in order to conserve Southeast Asian newts but the lack of data on the species and number of individuals impacted by the pet trade makes it difficult to monitor and accurately assess its threat. We strongly recommend that all Southeast Asian newts be listed on the CITES. This measure should improve monitoring of trade and provides importing countries opportunity to curb trade in species that were illegally harvested, thus helping to safeguard wild populations.
\end{abstract}

\title{
1. Introduction
}

The international wildlife trade is one of the leading threats to biodiversity conservation. This threat is disproportionally large in Southeast Asia, a region that is both a centre for the consumption of wildlife products and a major supplier of wildlife to the international market (Nijman, 2010; Sodhi et al., 2004; TRAFFIC, 2008,). The unsustainable, and often illegal, harvest of animals from the wild in Southeast Asia has already resulted in species population declines and extirpations (Duckworth et al., 2014; Rao et al., 2014; Stuart et al., 2006; van Schingen et al., 2014).

The global trade in amphibian species is widespread, involves hundreds of species, and has been implicated in driving local amphibian population declines (Jennings and Hayes, 1985; Wang et al., 2004). In Southeast Asia, amphibians are harvested from the wild to supply the demand for food, pets, and traditional medicine (Rowley et al., 2010). The pet trade is a major driving force behind the wildlife trade in Southeast Asia (Sodhi et al., 2004) and has been identified as causing population declines in at least one species of amphibian in Southeast Asia, the Lao Newt Laotriton laoensis (Phimmachack, et al. 2012; Stuart et al., 2006).

Recently, global attention has been drawn to the international trade in Asian newt species as vectors for the introduction of the pathogen Batrachochytrium salamandrivorans (Bsal) into Europe (Martel et al., 2014). This pathogen threatens the survival of newts and salamanders native to Europe, and potentially those in North America (Gray et al., 2015; Martel et al., 2014, Yap et al., 2015). A temporary ban on importing Asian newts has been proposed for the sake of native population of 
European and North American salamanders (Gray et al., 2015, Yap et al., 2015). Thus, curbing trade in Asian newts may have the unintended benefit of also protecting wils salamander populations elsewhere in the world (Stuart et al., 2014).

Fifteen species of newt in three genera (Laotriton, Paramesotriton and Tylototriton) are currently known from four countries in Southeast Asia: Laos, Myanmar, Thailand and Vietnam (Frost, 2016). Over $70 \%$ are endemic to the region (Frost, 2016). Our understanding of newt diversity in the region has changed dramatically in recent years, with the number of species recognised from the region increasing threefold since 2000 (Frost, 2016). This is a result of increased survey effort and the incorporation of molecular data in resolving species boundaries in the morphologically conserved taxa (Le et al., 2015; Nishikawa et al. 2013, 2014; Phimmachak et al., 2015a; Stuart et al. 2010). Undescribed diversity likely remains (Nishikawa et al., 2013, Sparreboom, 2014) and the basic biology, ecology and true conservation status of known Southeast Asian newts remains poorly-known (Phimmachak et al., 2015b).

At present, global conservation status assessments are available for only about half of all Southeast Asian newt species (IUCN, 2015), and most others have not been assessed in more than a decade (prior to taxonomic revision). Of the nine assessed species, five are considered threatened with extinction, and three are near threatened (Table 1). Tylototriton verrucosus is the only species of newt in Southeast Asia that is currently considered Least Concern, but since the assessment was performed (van Dijk et al., 2009), new research has shown that this species actually consists of a a complex of several species, each having narrower ranges and thus more likely to be threatened (e.g., Nishikawa et al., 2013, 2014; Phimmachak et al., 2015a; Le et al., 2015;). For example, one recently described species previously thought to be $T$. verrucosus, $T$. shanorum, is endemic to Myanmar (Nishikawa et al., 2014), where it is currently known only from a few ponds at risk of development (G. Wogan, pers. comm).

According to the IUCN (2015), collection for the pet trade is considered a threat to all Southeast Asian newt species except Paramesotriton guangxiensis and Tylototriton vietnamensis (although both these species are in the pet trade and so may also be threatened by the trade; Sparreboom, 2014). The pet trade is the primary driver for population declines of Laotriton laoensis (IUCN SSC ASG 2014; Phimmachak et al., 2012; Stuart et al., 2006). Despite this, there has been little attempt to assess the impact of the collection for the pet trade on wild Southeast Asian newt populations (but see Anonymous, 2013).

To gain a better understanding of the nature and scale of the trade in Southeast Asian newts we examined import records from the US, EU and Hong Kong, surveyed global online trade and surveyed local pet traders within Southeast Asia.

\section{Methods}

We obtained records of shipments of Southeast Asian newts into or out of the United States, from 2005 to 2014 (Yap et al., 2015), and from the USFWS Law Enforcement Management Information System (LEMIS). For import records of Southeast Asian newts into the EU, we downloaded available data from the CITES Trade Database (2011- 2013; http://trade.cites.org/en/cites_trade, downloaded April 2014). Species in the genera Laotriton, Paramesotriton and Tylototriton have been listed on Annex D of the European Union Wildlife Trade Regulations since 2009. We also obtained records of newts imported into Hong Kong from November 1998 to June 2015 from the Agriculture, Fisheries 
and Conservation Department of the Hong Kong Special Administrative Region Government (Appendix 1). We used these data because of their availability; similar data was unavailable for other countries, including those that are likely significant importers of Southeast Asian newts, notably Japan and mainland China.

We conducted an online survey for Asian newts in the pet trade by searching via Google and directly via websites and forums selling amphibians (Appendix 2) using scientific species names and common names in English, Vietnamese, Mandarin, Japanese, German, Dutch and Spanish. Although we attempted to be comprehensive, we likely missed non-English language sites as many sites did not list scientific names in identifying animals for sale, and common names were often not species specific or reliable. When possible, information on prevalence, origin and cost were gathered from websites.

Vietnam contains the highest species diversity of newts of any of the four Southeast Asian countries. As such, we used Vietnam as a case study to assess the local trade in Southeast Asian newts for both pets and traditional medicine. We investigated local trade in Hanoi and Ho Chi Minh City. In Hanoi we surveyed 25 stores ( 20 pet/aquarium shops, one free-lance trader, and four traditional medicine stores) on 25 \& 26 July 2015. In Ho Chi Minh City we visited 10 stores (seven pet/aquarium shops, and three traditional medicine stores) from 29 November to 5 December 2015.

\section{Results}

Between 2005 and 2014, 7508 individuals of four species of Southeast Asian newts were recorded as being imported live into the US: L. laoensis, P. deloustali, T. shanjing and T. verrucosus (Fig. 1). In addition, 1194 specimens reported only to the genus Paramesotriton or Tylototriton, and therefore potentially from Southeast Asia, were also reported. The Southeast Asian newt species recorded as being imported into the US in the greatest numbers is T. verrucosus, which accounted for $72 \%$ of all imports into the US between 2005 and 2014 (6822 individuals); 4240 individuals were imported into the US in 2007 alone.

The vast majority (87\%) of Southeast Asian newts imported into the US were identified as wildcaught, with only $11 \%$ (imported from Hong Kong, Germany, Canada and Vietnam) identified as captive bred and $2 \%$ as farmed. There was no clear trend in the volume of Southeast Asian newts being imported into the US over time, with 2005, 2007 and 2011 being the years of highest imports and 2012-2014 having relatively low numbers imported (Fig. 1).

A total of 718 individuals of four species of Southeast Asian newts were recorded as being imported live into the EU from 2011-2013: L. laoensis (41), T. asperrimus (367), T. verrucosus (300) and T. vietnamensis (10). A total of 120 of the T. asperrimus were recorded as being wild caught, and the remainder $(83 \%)$ were recorded as being from an unknown source. Over $90 \%$ of the newts recorded as being imported into the EU were imported into Germany. Of the Southeast Asian newts documented as being imported into the EU, $83 \%$ were imported from mainland China, $10 \%$ from Hong Kong, 6\% from Japan and 1\% from Vietnam.

Hong Kong appears to be serving as a transit hub for the Southeast Asian newt trade, with 908 wild caught and 2216 reportedly captive-bred or farmed, non-native $P$. deloustali, $T$. shanjing, and $T$. verrucosus (plus 839 wild caught Paramesotriton sp. and Tylototriton sp.). All of these were subsequently imported into the US. Only 20 newts potentially from Southeast Asia (T. verrucosus, imported from Japan) were recorded as being imported into Hong Kong via the international airport from November 1998 to June 2015 (of 7815 newts recorded). 
We found five Southeast Asian newt species for sale on the internet, L. laoensis, P. deloustali, T. asperrimus, $T$. shanjing and $T$. verrucosus (Table 1 ). The most commonly advertised species was $T$. verrucosus, which sold for relatively low values (average USD30). Of particular note is L. laoensis, which was found for sale on seven sites in three countries (Hong Kong, Japan and the US) at a high price (average USD259).

Southeast Asian newts were found listed for sale online as pets in 15 countries; Austria, Germany, Hong Kong, Italy, Japan, Malaysia, the Netherlands, Poland, Spain, the UK (England, Scotland, Wales), the US and Vietnam. Most records of Southeast Asian newts for sale were in the US (38\%) and UK (33\%). Of note, T. asperrimus and T. shanjing were both listed for sale in the US but there were no records of their import into the US through the end of 2014.

In Hanoi, of the 25 stores surveyed only nine had any information about newts as pets (none had information about newts for traditional medicine). None of these stores had any newts at the time but several traders said that they could provide the newts if ordered. The traders said they could buy newts from local residents who collect wild animals, and one trader said he could obtain newts from Tay Yen Tu (Bac Giang province, the type locality of T. vietnamensis). Another trader also reported sending newts to Ho Chi Minh City, a large city in Vietnam that is far outside of the native range of newts (Le et al. 2015). The price of purchasing newts as pets in Hanoi was USD13-22 (VND300 000-500 000). In Ho Chi Minh City, of the ten stores surveyed, only one had any newts for sale as pets (>100 individuals of Cynops orientalis, a species that is endemic to China), two reported that they used to have newts for sale (Cynops spp. and Paramesotriton deloustali respectively), and one reported that they could order Cynops spp. None of the three traditional medicine stores had newts for sale. Paramesotriton deloustali were also found online (on Facebook) for sale as pets in Ho Chi Minh City for USD7 (VND150 000) each. Many pet stores and traders in Hanoi said that they had stopped selling newts in recent years due to low demand for pets from both domestic and international markets.

\section{Discussion}

Large numbers of Southeast Asian newts are harvested from the wild to meet the demands of the international pet trade. This trade is almost all unregulated and unrecorded, and as such we were only able to gain a glimpse into the trade via US, EU and Hong Kong import data and a subset of the online trade. Unfortunately, this is not a unique situation; much of the global trade in wildlife is not recorded in government statistics (Broad et al., 2003), and/or is illegal (Roe, 2008; TRAFFIC, 2008) and any trade figures obtained represent only a fraction of the actual volume of wildlife traded (Sodhi et al. 2004). Countries that we found to have a relatively large presence in the online trade, such as the Japan, do not currently have data available on the import or export of newts. In addition, our online searches revealed reportedly wild caught Southeast Asian newts for sale belonging to species that were not recorded as having been imported into the EU (eg. Tylototriton yangi was advertised for sale online from a supplier in Italy).

With the available data, it was not possible to obtain estimates of the numbers of each species exported from Southeast Asian countries. There are no newt export records available from these countries, and most Southeast Asian newt species that were recorded as being imported into the US are native to countries that were not listed on documents. For example, only eight individuals of 
Vietnam-endemic $P$. deloustali were reported as being exported from Vietnam, despite most being listed as wild caught).

Local reports indicate that the scale of harvest of Southeast Asian newts is far greater than the limited number of trade statistics suggest. For example, in April 2008, villagers in Xiengkhouang Province in Laos, reported selling 300-400 individuals of the Laos-endemic L. laoensis per year to visiting European or Japanese collectors for LAK5 000-15 000 ( USD0.60-1.76) each (IUCN SSC ASG, 2014; Phimmachack et al., 2012). In June 2009, local residents in Luangphabang Province also reported selling hundreds of L. laoensis in January 2009 to a visiting Chinese collector for LAK30 000 ( USD3.5) per kg (<USD0.20 per individual;IUCN SSC ASG. 2014). There are also recent (2015) reports of a market in Xiengkhouang Province selling L. laoensis for as little as LAK150 000/kg ( USD18/kg), approximately LAK10 000 ( USD1.20) per individual (S. Phimmachack, pers obs). Laotriton laoensis are also regularly been observed for sale as pets outside of their native range in Chatuchak market, Bangkok, Thailand (S. Phimmachack, pers obs).

The demand for Southeast Asian newts as pets is global in nature, and we found records of Southeast Asian newts for sale throughout Europe, Asia and the Americas. Our online searches revealed most records of Southeast Asian newts for sale in the US and UK but this may be at least partly a reflection of language bias in searches for common names and because scientific names are often not used.

Internet trade surveys conducted in 2011 (Anonymous, 2013) revealed fewer Southeast Asian species in the internet trade. The report listed L. laoensis, T. shanjing, and T. verrucosus in the internet trade, but not two species that we detected, $P$. deloustali and T. asperrimus, both of which were described at the time. The prices reported in the survey for these species were similar to those recorded by us. In 2011, L. laoensis was reported for sale for USD240, similar to the average price we recorded (USD259), T. shanjing was USD28 (compared to our average of USD59) and T. verrucosus was USD39 (compared to USD30). The number of recorded instances of Southeast Asian newts for sale on the internet was much lower in the 2011 report (Anonymous, 2013), with six records versus 50 in our study, which may indicate an increase in trade, but it is difficult to compare search effort and efficiency.

Species identification is likely to be a significant source of error in any reporting of Southeast Asian newt species. In the LEMIS data, Southeast Asian newts were often not identified to species and were listed as "Paramesotriton sp." and "Tylototriton sp." Morphological identification in this group is difficult or even impossible by a non-specialist, and to further complicate matters, the origin of the imported animals was often unknown. For example, regardless of specific identity, Chinese newts obtained via the pet trade are often labeled P. chinensis (Sparreboom, 2014). Several of the newly described Tylototriton species were previously confused with T. verrucosus and are likely have been, and continue to be, traded under this name, erroneously or deliberately.

The trade in newts within Southeast Asia appears negligible in comparison to the international trade. Newts are used for traditional medicine and pets within Vietnam, Myanmar and Laos (Rowley et al., 2010). However, their use in Vietnam seems to be declining (Anonymous, 2013; T. Q. Nguyen pers. obs.) and they are no longer found commonly in open markets in Vietnam (Anonymous, 2013; Nguyen and Ho, 2004). Species of native newts (Laotriton and Tylototriton) are used for traditional medicine in Laos, but at relatively low levels (Phimmachak et al., 2012; Phimmachak et al., 2015b). Systematic surveys of shops in other countries in the region are needed to determine if this trend is widespread. 
The lack of data on the nature and scale of the trade makes it impossible to monitor and accurately assess the threat of the international pet trade on Southeast Asian newts. While several species are protected within their range countries, weak enforcement of this protection is a significant barrier to conservation efforts, and no Southeast Asian newts are listed in the Convention on International Trade in Endangered Species of Wild Fauna and Flora (CITES) (Rosser et al., 2001), the international agreement that monitors and regulates international trade in wildlife. Kaisers Spotted Newt (Neurergus kaiseri), endemic to Iran, is the only newt (family Salamandridae) listed in CITES at present. This Critically Endangered species (IUCN 2015) was listed in CITES Appendix I in response to illegal export to Europe and Japan for the pet trade in violation of Iranian national law (CITES 2010).

Regardless of the protection status of the Southeast Asian newt species in their range countries, the fact that none are listed in CITES means that trade in these species is not reported or regulated in all importing states. The Lacey Act in the US aids in prohibiting the import of species illegally sourced in range states, but is easily circumvented by laundering animals through the EU or other states, and declaring them as being captive-bred there. There is no equivalent legislation in the EU, resulting in the legal import of Southeast Asian newt species regardless whether or not they were legally sourced (Vinke and Vinke, 2015). Listing all Southeast Asian newt species in Appendix I or II of CITES (or Appendix III for species endemic to a single country) would allow for better monitoring and regulation. All range countries are Party to the Convention, as are the major importing countries.

To understand the impact of the pet trade on Southeast Asian newt species it is necessary to not only understand the level of harvest and trade, but also the link between harvesting levels and population declines. Population monitoring of Southeast Asian newts, and more information on their biology and ecology (eg. Bernardes et al., 2013; Phimmachak et al., 2015b) is urgently required. The threat of harvesting must also not be considered alone. In all likelihood, the greatest threat to Southeast Asian newts is habitat loss (Rowley et al., 2010), and it is considered a threat to most Southeast Asian newt species that have been assessed (IUCN, 2015). Particularly when combined with habitat loss, climate change and disease, the harvesting of Southeast Asian newts from the wild has the potential to drive species to extinction.

As our understanding of species boundaries in Southeast Asian newts improves, it is becoming apparent that there may be no truly widespread, common species. All Southeast Asian newt species are likely to have relatively restricted ranges and therefore higher risk of extinction than currently understood. Particularly in the face of other threats (Rowley et al., 2010), it is vital that the nature and scale of harvesting of Southeast Asian newts be better understood and managed. Two East Asian newt species have already been extirpated in all or a significant part of their ranges (Lau et al., 2007), and at least one Southeast Asian newt is perilously close to being driven to extinction in the wild primarily due to the pet trade (Stuart et al., 2014). The threat of the illegal pet trade to Asian newts is such that a recent publication describing a new newt species from China, Echinotriton maxiquadratus, did not reveal the collection locality and made the specific request that "all hobbyists...refrain themselves from collecting this salamander or leaking locality information if encountered, and boycott any trading" (Hou et al., 2014; pp 89.).

Given that international trade is a major threat, we strongly recommend that all Southeast Asian newts be listed in CITES so that their trade is monitored, and the data can be used to inform conservation decisions and safeguard these species from over-harvesting. Listing these species in the Appendices of CITES would also provide mechanisms to control and regulate the trade in importing countries. Significant difficulties in identifying individual species would greatly hamper implementation of 
CITES, and therefore we recommend that Laotriton, Paramesotriton and Tylototriton be listed in the Appendices of CITES at the genus level.

An additional threat is posed by the largely unregulated trade of Asian newts. Three Asian salamander species have been suggested to serve as reservoirs to the recently discovered pathogen Bsal: Cynops pyrrogaster, C. cyanurus, and Paramesotriton deloustali, while other Asian species (e.g. Tylototriton wenxianensis) are highly vulnerable. Based upon this information and phylogenetic relationships among the Asian newts, it is likely that other Southeast Asian newts are also reservoirs to Bsal (Stuart et al., 2014). As such, the global trade in Asian newts has potential to transport Bsal to naiive populations of salamanders elsewhere in the world (Yap et al., 2015; Stuart et al., 2014). Very little is known about the pathogen itself, disease dynamics, and impact on host populations. Additional measures such as disease screening within native ranges for additional newt species will be necessary to understand the potential conservation impacts of this pathogen within Asia as well as to stem the inadvertent import of pathogens on these, and other amphibians, as they are transported around the world.

\section{Acknowledgements}

The Agriculture, Fisheries and Conservation Department of the Hong Kong Special Administrative Region Government provided trade data for newts and salamanders. Hai Bui \& Hai Ngo carried out market surveys in northern Vietnam and and Đỗ Minh Nghĩa, Phạm Nguyễn Ngọc Minh and Tăn Tuấn Nghĩa carried out market surveys in Ho Chi Minh City. Niane Sivongxay (National University of Laos) and staff of the Wildlife Conservation Society Laos Program assisted with obtaining trade data on Laotriton. Tanya Chan-ard provided valuable information on the trade in Thailand. Stiftung Artenschutz and Wildlife Reserves Singapore provided support for this project. JJLR was supported by ADM Capital Foundation, BLS was supported by the U.S. National Science Foundation (DEB1145922), TQN was supported by the Vietnam National Foundation for Science and Technology Development (NAFOSTED; grant number 106-NN.05-2014.34), and GOUW was supported by the Declining Amphibian Task Force and the U.S. National Science Foundation (DEB-9971861, DEB0451832). For all this assistance we are most grateful.

\section{References}

Anonymous., 2013. Striking, vulnerable and in demand: The Trade in Indochinese Newts. https://www.yumpu.com/en/document/view/15870896/striking-vulnerable-and-in-demand-thetrade-in-indochinese-newts (accessed 29.09.15).

Beissinger, S.R., 2001. Trade of live wild birds: potentials, principles, and practices of sustainable use, in Reynolds, J.D., Mace, G.M., Redford, K.H., Robinson, J.G. (Eds.), Conservation Biology Series, Cambridge, pp.182-202.

Bernardes, M., Rödder, D., Nguyen, T.T., Pham, C.T., Nguyen, T.Q., Ziegler, T., 2013. Habitat characterization and potential distribution of Tylototriton vietnamensis in northern Vietnam. J. Nat. Hist. 47, 1161-1175.

Bickford, D., Howard, S.D., Ng, D.J., Sheridan, J.A., 2010. Impacts of climate change on the amphibians and reptiles of Southeast Asia. Biodivers. Conserv. 19, 1043-1062. 
Convention on International Trade in Endangered Species of Wild Fauna and Flora [CITES] (2010). Considerations for Proposals of Amendment of Appendices I and II, CoP15 Prop.14, Doha, Qatar. http://www.cites.org/eng/cop/15/prop/E-15\%20Prop-14.pdf_(accessed 2.4.16).

Duckworth, J.W., Batters, G., Belant, J.L., Bennett, E.L., Brunner, J., Burton, J., Challender, D.W.S., Cowling, V., Duplaix, N., Harris, J.D., Hedges, S., Long, B., Mahood, S.P., McGowan, P.J.K., McShea, W.J., Oliver, W.L.R., Perkin, S., Rawson, B.M., Shepherd, C.R., Stuart, S.N., Talukdar, B.K., van Dijk, P.P., Vié, J-C., Walston, J.L., Whitten, T., Wirth, R., 2012. Why South-East Asia should be the world's priority for averting imminent species extinctions, and a call to join a developing cross-institutional programme to tackle this urgent issue. Sapiens. 5, 77-95.

Fisher, M.C., Garner, T.W., 2007. The relationship between the emergence of Batrachochytrium dendrobatidis, the international trade in amphibians and introduced amphibian species. Fungal Biol. Rev. 21, 2-9.

Frost, D.R., 2016. Amphibian Species of the World: an Online Reference. Version 6.0 (25 March 2016). http://research.amnh.org/herpetology/amphibia/index.html. American Museum of Natural History, New York, USA (accessed 02.04.16).

Gratwicke, B., Evans, M.J., Jenkins, P.T., Kusrini, M.D., Moore, R.D., Sevin, J., Wildt, D.E., 2009. Is the international frog legs trade a potential vector for deadly amphibian pathogens? Front. Ecol. Environ. 8, 438-442.

Gray M.J., Lewis J.P., Nanjappa, P., Klocke, B., Pasmans, F., Martel, A., Stephen, C., Parra, O.G., Smith, S.A., Sacerdote-Velat, A., Christman, M.R., 2015. Batrachochytrium salamandrivorans: The North American response and a call for action. PLoS Pathog. 11, e1005251.

Hou, M., Wu, Y., Yang, K., Zheng, S., Yuan, Z., Li, P., 2014. A missing geographic link in the distribution of the genus Echinotriton (Caudata: Salamandridae) with description of a new species from southern China. Zootaxa, 3895, 89-102.

IUCN SSC Amphibian Specialist Group, 2014. Laotriton laoensis. The IUCN Red List of Threatened Species 2014: e.T59461A47152908. http://dx.doi.org/10.2305/IUCN.UK.20141.RLTS.T59461A47152908.en (accessed 26.09.15).

IUCN, 2015. The IUCN Red List of Threatened Species. Version 2015-4. http://www.iucnredlist.org. Downloaded on (accessed 26.09.15).

Jennings, M.R., Hayes, M.P., 1985, Pre-1900 overharvest of California red-legged frogs (Rana aurora draytonii): the inducement for bullfrog (Rana catesbeiana) introduction. Herpetologica, 1985, 94-103.

Karesh, W.B., Cook, R.A., Bennett, E. L., Newcomb, J., 2005. Wildlife trade and global disease emergence. Emerg. Infect. Dis. 11, 1000-1002.

Lau, M.W.N., Chanson, S.N.S.J.S., Cox, N.A., Fischman, D.L., 2007. Conservation needs of amphibians in China. Scientia Sinica Vitae, 50, 265-276. 
Le, D.T., Nguyen, T.T., Nishikawa, K., Nguyen, S.L.H., Pham, A.V., Matsui, M., Bernardes, M., Nguyen, T.Q., 2015. A new species of Tylototriton Anderson, 1871 (Amphibia: Salamandridae) from northern Indochina. Current Herpetol. 34, 38-50.

Martel, A., Blooi, M., Adriaensen, C., Van Rooij, P., Beukema, W., Fisher, M.C., Farrer, R.A., Schmidt, B.R., Tobler, U., Goka, K., Lips, K.R. (2014). Recent introduction of a chytrid fungus endangers Western Palearctic salamanders. Science, 346, 630-631.

Mccallum, M.L., Bury, G.W., 2013. Google search patterns suggest declining interest in the environment. Biodivers. Conserv. 22, 1355-1367.

Min, S. 2012. Impacts of Wildlife Trade on Conservation in Kachin State, Myanmar. Traffic Bulletin, Cambridge UK, 24, 57-64.

Nguyen Q.T., Ho, C.T., 2004. Baseline surveys and training for monitoring of key species of reptiles and amphibians in Tam Dao National Park. Technical Report for Tam Dao National Park and Buffer Zone Management Project: 44 pp.

Nguyen, X.D., 2004. Investigation of the trade in wildlife, insects and ornamental plants and their socio-economic contribution to local communities in the Tam Dao National Park and buffer zones. Tam Dao National Park, Hanoi.

Nguyen, X.D., Nguyen, V.S., Truong, V.L., Ngo, X.T., Nguyen, Q.T., 2003. Evaluation of the wildlife trade in Ba Be and Cho Don Districts, PARC Project VIE/95/G31\&031, Government of Viet Nam (FPD) /UNOPS/UNDP/Scott Wilson Asia-Pacific Ltd., Ha Noi.

Nijman, V., 2010. An overview of international wildlife trade from Southeast Asia. Biodivers. Conserv. 19, 1101-1114.

Nijman, V., Shepherd, C.R., 2011. The role of Thailand in the international trade in CITES-listed live reptiles and amphibians. PloS One, 6, e17825.

Nishikawa, K., Khonsue, W., Pomchote, P., Matsui, M., 2013) Two new species of Tylototriton from Thailand (Amphibia: Urodela: Salamandridae). Zootaxa, 3737, 261-279.

Nishikawa, K., Matsui, M., Rao, D., 2014. A new species of Tylototriton (Amphibia: Urodela: Salamandridae) from central Myanmar. Nat. Hist. Bull. Siam Soc. 60, 9-22.

Phimmachak, S., Aowphol, A., Stuart, B.L., 2015a. Morphological and molecular variation in Tylototriton (Caudata: Salamandridae) in Laos, with description of a new species. Zootaxa, 4006, 285-310.

Phimmachak, S., Stuart, B.L., Aowphol, A., 2015b. Ecology and natural history of the knobby newt Tylototriton podichthys (Caudata: Salamandridae) in Laos. Raff. Bull. Zool. 63, 389-400.

Phimmachak, S., Stuart, B.L., Sivongxay, N., 2012. Distribution, natural history, and conservation of the Lao Newt Laotriton laoensis (Caudata: Salamandridae). J. Herpetol. 46, 120-128.

Rao, M., Duckworth, J. W., Roberts, R. \& Shepherd, C. R. (2014). Averting the imminent extinction of South-east Asian vertebrate species: Asian Species Action Partnership (ASAP). TRAFFIC Bulletin, 26(1), 15-17. 
Raghavan, R., Dahanukar, N., Tlusty, M.F., Rhyne, A.L., Kumar, K.K., Molur, S., Rosser, A.M., 2013. Uncovering an obscure trade: threatened freshwater fishes and the aquarium pet markets. Biol. Conserv. 164, 158-169.

Rosser, A., Haywood, M., Harris, D., 2001. CITES: A Conservation Tool. IUCN Species Survival Commission, Cambridge, UK.

Rowley, J., Brown, R., Kusrini, M., Inger, R., Stuart, B., Wogan, G., Chan-ard, T., Cao, T.T., Diesmos, A., Iskandar, D.T., Lau, M., Ming, L.T., Makchai, S., Neang, T., Nguyen, Q. T., Phimmachak, S., 2010. Impending conservation crisis for Southeast Asian amphibians. Biol. Lett. 6, 336-338.

Schlaepfer, M.A., Hoover, C., Dodd, C.K., 2005. Challenges in evaluating the impact of the trade in amphibians and reptiles on wild populations. BioScience, 55, 256-264.

Sodhi, N.S., Koh, L.P., Brook, B.W., Ng, P.K., 2004. Southeast Asian biodiversity: an impending disaster. Trends Ecol. Evol. 19, 654-660.

Sparreboom, M., 2014. Salamanders of the old world. Knnv Publishing, Zeiss.

Stuart, B.L., Phimmachak, S., Sivongxay, N., Robichaud, W.G., 2010. A new species in the Tylototriton asperrimus group (Caudata: Salamandridae) from central Laos. Zootaxa, 2650, 1932 .

Stuart, B.L., Rhodin, A.G., Grismer, L.L., Hansel, T., 2006. Scientific description can imperil species. Science, 312, 1137-1137.

Stuart, B.L., Rowley, J.J.L., Phimmachak, S., Aowphol, A., Sivongxay, N., 2014. Salamander protection starts with the newt. Science, 346, 1067-1068.

TRAFFIC (2008). What's Driving the Wildlife Trade? A Review of Expert Opinion on Economic and Social Drivers of the Wildlife Trade and Trade Control Efforts in Cambodia, Indonesia, Lao PDR and Vietnam. East Asia and Pacific Region Sustainable Development Discussion Papers. East Asia and Pacific Region Sustainable Development Department, World Bank, Washington, DC.

van Dijk, P.P., Wogan, G., Lau, M.W.N., Dutta, S., Shrestha, T.K., Roy, D., Nguyen T.Q., 2009. Tylototriton verrucosus. The IUCN Red List of Threatened Species 2009: e.T59487A11934912. http://dx.doi.org/10.2305/IUCN.UK.2004.RLTS.T59487A11934912.en..

van Schingen, M., Pham, C. T., Thi, H. A., Bernardes, M., Hecht, V., Nguyen, T.Q., Bonkowski, M., Ziegler, T., 2014. Current status of the Crocodile Lizard Shinisaurus crocodilurus Ahl, 1930 in Vietnam with implications for conservation measures. Rev. Suisse Zool. 121, 425-439.

Vinke, T., Vinke, S., 2015. Kann und darf Illegales in der Europäischen Union legal sein? Schildkröten im Fokus, Bergheim 12, 30-35.

Wang, X.M., Zhang, K.J., Wang, Z.H., Ding, Y.Z., Wu, W., Huang, S., 2004. The decline of the Chinese giant salamander Andrias davidianus and implications for its conservation. Oryx, 38, 197-202. 
Wu, Y., Rovito, S.M., Papenfuss, T.J., Hanken, J., 2009. A new species of the genus Paramesotriton (Caudata: Salamandridae) from Guangxi Zhuang Autonomous Region, southern China. Zootaxa, 2060, 59-68.

Yap, T.A., Koo, M.S., Ambrose, R.F., Wake, D.B., Vredenburg, V.T., 2015. Averting a North American biodiversity crisis. Science, 349, 481-482. 
Table 1. Southeast Asian (Laos, Myanmar, Thailand and Vietnam) newt diversity, distribution, threats, protected status and detected presence in commercial trade.

\begin{tabular}{|c|c|c|c|c|c|c|c|c|}
\hline Species & $\begin{array}{l}\text { Year } \\
\text { described }\end{array}$ & $\begin{array}{l}\text { Endemic } \\
\text { to SE Asia }\end{array}$ & Range & $\begin{array}{l}\text { Threat } \\
\text { Status }\end{array}$ & Protected status & $\begin{array}{l}\text { In trade } \\
2015 \\
\text { (online)* }\end{array}$ & $\begin{array}{l}\text { In trade } \\
\text { (LEMIS } \\
\text { 2005- } \\
\text { 2014)*** } \\
\end{array}$ & $\begin{array}{l}\text { In trade } \\
\text { (EUWTR } \\
\text { 2011-2013) }\end{array}$ \\
\hline Laotriton laoensis & 2002 & Yes & Laos & EN & Laos & $259(7)$ & Yes & Yes \\
\hline Paramesotriton deloustali & 1934 & Yes & Vietnam & VU & Vietnam & $7(4)$ & Yes & \\
\hline Paramesotriton guanxiensis & 1983 & No & China, Vietnam & $\mathbf{E N}$ & & & & \\
\hline Tylototriton anguliceps & 2015 & Yes & Laos, Thailand, Vietnam & NA & Thailand pending? & & & \\
\hline Tylototriton asperrimus & 1930 & No & China, Vietnam & NT & & $70(5)$ & & Yes \\
\hline Tylototriton notialis & 2010 & Yes & Laos, Vietnam & $\mathbf{V U}$ & & & & \\
\hline Tylototriton panhai & 2013 & Yes & Laos, Thailand & NA & Thailand pending? & & & \\
\hline Tylototriton podichthys & 2015 & Yes & Laos & NA & & & & \\
\hline Tylototriton shanjing & 1995 & No & China, Thailand & NT & & $59(12)$ & & \\
\hline Tylototriton shanorum & 2014 & Yes & Myanmar & NA & & & & \\
\hline Tylototriton uyenoi & 2013 & Yes & Thailand & NA & Thailand pending? & & & \\
\hline Tylototriton verrucosus & 1871 & No & Bhutan, China, India, Thailand & LC & Thailand & $30(23)$ & Yes & Yes \\
\hline Tylototriton vietnamensis & 2005 & Yes & Vietnam & NT & Vietnam & & Yes & Yes \\
\hline Tylototriton ziegleri & 2013 & Yes & Vietnam & $\begin{array}{l}\text { NA } \\
\text { (VU) }\end{array}$ & & & & \\
\hline Paramesotriton sp. & & & & & & & Yes & \\
\hline Tylototriton sp. & & & & & & & Yes & \\
\hline
\end{tabular}




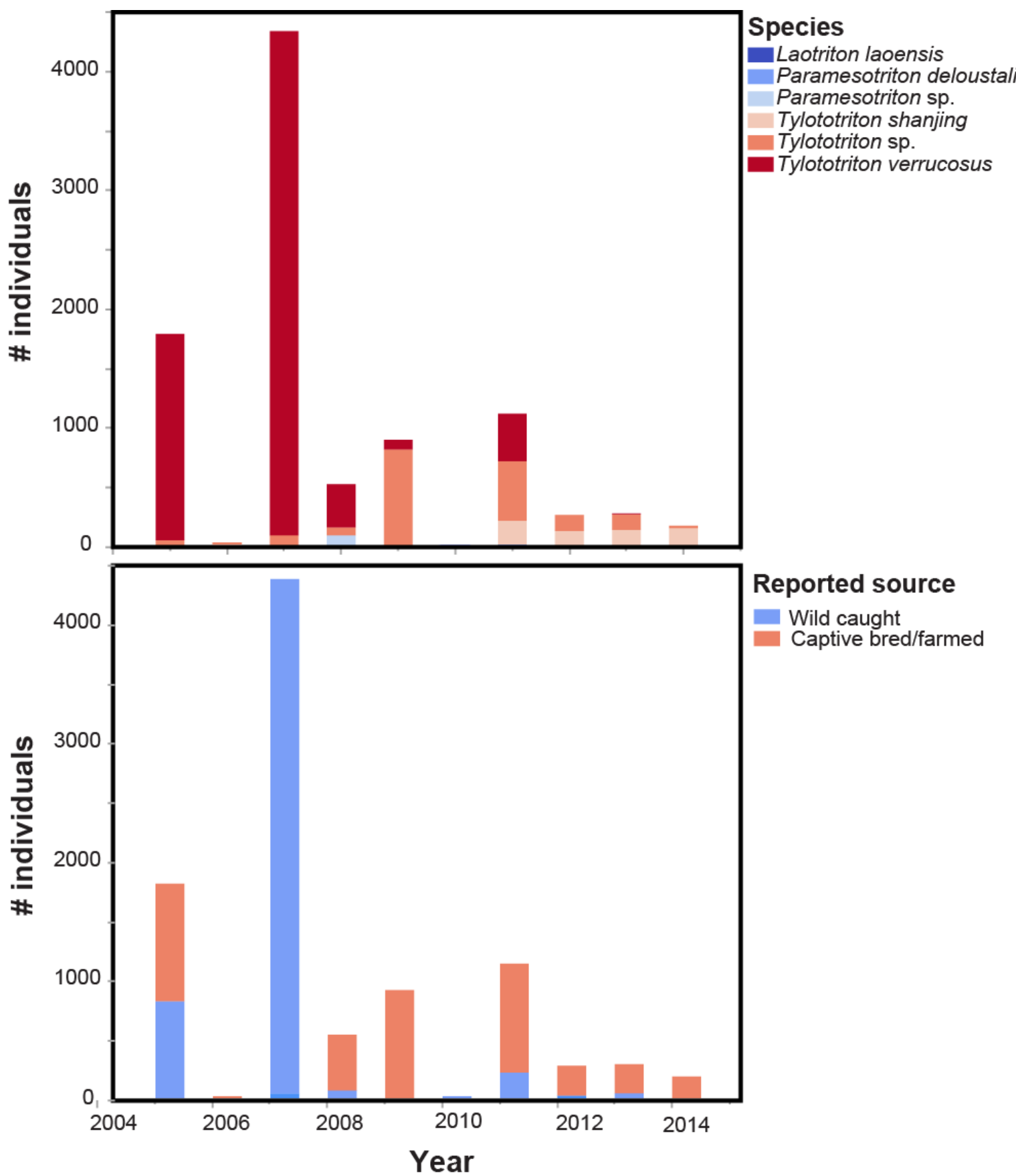

Figure 1. Number of individuals of Southeast Asian (Laos, Myanmar, Thailand and Vietnam) newts, (or newts potentially from Southeast Asia (Paramesotriton sp. and Tylototriton sp.), imported into the US during 2005-2014 (LEMIS) by species and by source (wild caught versus captive or farmed). A total of 15 individuals of Laotriton laoensis were recorded as being imported into the US in 2010 and in 2011 , all reportedly captive bred. 